\title{
Issues of Cooperative Learning in ESL Classes: A Literature Review
}

\section{Xiaoping Liang, Bernard A. Mohan, and Margaret Early}

This article reviews the research literature on cooperative learning in the second language (L2) classroom in relation to $L 2$ acquisition, maintenance of first language (L1), the integration of language and content learning, and L2 learners' perceptions, and discusses some issues and problems of this educational innovation in an English as a second language (ESL) context. Although acknowledging the reported potential benefits of cooperative learning for L2 learners, it calls for further research to examine the types of $L 1$ and $L 2$ discourse produced in cooperative groups and find out about student development of academic discourse, to investigate whether L1 use in cooperative groups affects the interracial and intercultural relationships between students who speak different L1s, to look at the role of students' prior knowledge in L1 in their learning of new content knowledge in $L 2$ in cooperative groups, and to explore how different groups of ESL students perceive cooperative learning and how cultural and educational backgrounds may influence their perceptions.

\section{Introduction}

In recent years, cooperative learning has emerged as a significant concept and instructional practice in the field of second language education. Attention has been paid to the pedagogical and psychological rationale of its use in second language classrooms (Long \& Porter, 1985) and to possible benefits it might have in bilingual programs and second or foreign language settings (Coelho, 1992, 1994; Cohen, 1994; Holt, 1993; Kessler, 1992; McGroarty, 1989, 1992). The optimum conditions for second language learning and those for cooperative learning are compared to see if they are in any way similar (Fathman \& Kessler, 1993). Instructional processes and planning of second language education are also compared with those of cooperative learning methods to see if there are any parallels (McGroarty, 1993). In addition, studies have been conducted to examine, among other things, the impact of cooperative learning on second language acquisition, maintenance of first language, the integration of language and content learning, and second language learners' perceptions. This article provides a critical review of the research literature on cooperative learning in these four areas and discusses some issues and problems of this educational innovation in an ESL context. 


\section{Cooperative Learning and Second Language Acquisition}

A commonly held belief in the field of second language education is that cooperative learning maximizes second language acquisition by providing opportunities for both language input and output (Fathman \& Kessler, 1993; Holt, Chips, \& Wallace, 1992; Long \& Porter, 1985; McGroarty, 1993). Compared with research on cooperative learning in mainstream education, research on cooperative learning in second language education is surprisingly less extensive. Although theorists take cooperative learning to be beneficial to second language learners, to date only a few studies have focused on cooperative learning and second language acquisition. In spite of the limited number of studies, the existing body of research seems to support the belief that cooperative learning offers second language learners more opportunities for interaction in L2 and helps them improve second language proficiency.

An early study on cooperative learning and interaction in L2 was carried out by Long, Adams, McLean, and Castaños (1976) in intermediate-level, adult ESL classes. The researchers compared teacher-led discussions with pair discussions to examine the amount and variety of student talk in both contexts. Their results reveal that students in pairs produced a significantly greater amount and variety of student talk than in the teacher-led discussions. They not only talked more, but also produced a wider range of language functions (e.g., rhetorical, pedagogical, and interpersonal).

In a study on the input available to and language produced by second language learners, Pica and Doughty (1985a, 1985b) compared teacherfronted discussions and small-group discussions in a classroom setting involving low-intermediate-level ESL students. They found that individual students had more opportunities to practice using English and engage in direct interaction in groups than in teacher-fronted discussions through taking more turns, producing more samples of the target language, and receiving more feedback from other group members. In an earlier report, Doughty and Pica (1984) compared language use in teacher-fronted lessons, group work, and pair work. They noted that significantly more negotiation for meaning, which is believed to enhance second language acquisition, occurred in groups (66\% of total talk) and in pairs (68\%) than in the wholeclass setting (45\%).

Also within an input/interaction framework, Pica (1987) reported on research involving low-intermediate level adult ESL students engaged in two types of classroom activities in a teacher-fronted setting and in small groups of four. It was found that the teacher-directed participation pattern generated a relatively small amount of modified interaction in both activities. The occurrence of such interactional moves as confirmation and comprehension checks and clarification requests, which are believed to be important to 
second language acquisition, was fairly low. The group participation pattern, on the other hand, presented a complex picture. Group participants produced significantly more interactional moves to clarify or confirm message content or check the comprehensibility of their utterances in one activity, but not in the other. In conclusion, Pica emphasized the importance not of group work per se, but of the nature of classroom activities to be accomplished in small groups.

In a situation where English was the L1 and Dutch was a foreign language, Deen (1987) analyzed classroom interactions in a cooperative learning situation and a teacher-centered situation and found that a cooperative jigsaw activity created many more practice opportunities for individual learners in a university Dutch class. Students asked far more questions of different kinds. By doing so, they produced input for each other and, at the same time, practiced natural use of the language. It was also noted that the proportion of errors in cooperative student work was far lower than that in teacher-led instruction, primarily because students had many more chances to use the language in cooperative work.

In addition to the focus on the impact of cooperative learning on the amount of interaction in L2, research has also been carried out to examine the effect of cooperative learning on second language proficiency. Sharan, Bejarano, Kussell, and Peleg's (1984) study involved junior high school Israeli students learning English as a second language. They compared cooperative learning methods with the whole-class method and found that cooperative learning resulted in better performance on an overall measure of English proficiency and on a listening comprehension subtest. The researchers suggest that students had opportunities to speak more frequently and to use different language structures in the small-group settings.

Research has also been conducted to evaluate the effect of cooperative learning on language proficiency in a foreign language learning situation. Bejarano (1987) reported on a study involving junior high school students learning English as a foreign language in Israel. Students in classes using cooperative learning methods were found to make significant improvements in an overall English proficiency test and in a listening comprehension subtest as opposed to students in classes using whole-class methods.

\section{Issues of Academic Language Development}

The existing body of research in the second language classroom appears to indicate that cooperative learning methods maximize second language learning by providing opportunities for both language input and output. Nevertheless, little research has looked at the kinds of discourse produced in small groups and examined the quality of L2 acquisition. In his discussion of language proficiency, Cummins (1984, 1992) distinguished between basic interpersonal communicative skills (BICS) and cognitive/academic lan- 
guage proficiency (CALP). Research based on Cummins' framework (Collier, 1987) suggests that although BICS are relatively easier to master, CALP takes much more time and effort. Regarding students' L2 achievement gained through cooperative learning methods as reported in the studies reviewed above, one must ask the question: What type of language is acquired, academic or basic conversation?

Jacob, Rottenberg, Patrick, and Wheeler's (1996) study is one of the few that explore L2 learners' acquisition of academic language in cooperative learning contexts. Their findings present a complex picture of the influence of the Learning Together method on opportunities for acquiring academic English in a grade 6 social studies class. Although they found a wide range of opportunities for L2 learners to acquire academic English, they also found that these opportunities occurred relatively infrequently. Many opportunities were missed. Of the opportunities that did occur, many were skewed toward simpler aspects of academic language. The most frequent opportunity in their study involved L2 students giving or receiving help with decoding academic terms.

Jacob et al.'s (1996) findings are supported by research in mainstream education. In his study of monolingual English-speaking students in the United Kingdom, Dowrick (1993) found that cooperative learning arrangements gave rise to $50 \%$ more low-order talk than high-order talk in a mathematics class. The major reason, as he sees it, was that partners had constantly to coordinate their actions so that talk was almost continuous in low-order mode. Dowrick defined low-order talk as talk that did not relate to mathematical aspects of the tasks or that merely described work done on them. High-order talk is defined as analyzing or evaluating mathematical aspects of the tasks, or giving explanations or reasons. In the studies on cooperative learning and second language acquisition described here, is the reportedly increased input and output high-order talk or low-order talk?

To answer this question, it is obvious that we need more studies of the quality of L2 discourse in cooperative learning situations. We need to look at the discourse produced by ESL students in cooperative learning groups to see whether it is high-order or low-order talk, or academic language, or basic conversation.

\section{Cooperative Learning and First Language Maintenance}

In the fields of second language and bilingual education, it is now believed that the use of first language (L1) is crucial in early L2 acquisition and is beneficial at all levels of L2 learning (Auerbach, 1993). Cooperative learning is claimed to have the capacity of helping second language learners draw on their primary language resources as they develop L2 skills.

McGroarty $(1989,1992)$ reviewed a small number of studies that researched the expanded possibilities of cooperative learning for using 
primary language resources. Cohen and her colleagues (Cohen, 1986) observed Spanish-English bilingual classrooms and noted that bilingual students in cooperative groups tended to provide necessary information to Spanish monolingual students and helped to extend or clarify their comprehension through discussion in their L1. Wong-Fillmore, Ammon, McLaughlin, and Ammon (1985) reported that, when working in groups, bilingual students acted as intermediaries, serving as crucial links in providing information to other group members in both languages. Neves' (1983) work revealed that the frequency of task-related talk in Spanish as the first language in cooperative groups was proportionately related to students' gains in English as a second language. Díaz, Moll, and Mehan (1986) found that student group discussion of a reading lesson in Spanish as the L1 helped improve reading comprehension in English as the L2. Deen (1987) reported that in a Dutch as a foreign language situation, more English (L1) was used to clarify the information to be conveyed, whereas more Dutch was used as students were doing the team project.

\section{Issues of L1 Academic Discourse Development}

Although the limited number of studies available seem to show that cooperative learning has the potential for increasing task-related use of the first language, it should be pointed out that a prime area of concern of most research on cooperative learning and first language maintenance is how the use of the first language can enhance second language development in cooperative groups. Little attention has been focused on the quality of student discourse in the first language. Even less attention has been given to the development of ESL students' academic discourse in the L1. Research shows that developing academic discourse for school purposes is important, complex, and takes considerable time (Collier, 1995). The question arises: Should ESL students develop academic discourse in both L1 and L2 or in just one language? And how would the answer to this question affect policy in the ESL classroom?

\section{Issues of L1 Use and Intercultural Relationships}

Most research on cooperative learning and first language maintenance is carried out in a bilingual classroom where only two languages are spoken. What happens when more than one first language is spoken in the classroom as is the case in many ESL settings? Whose first language is to be used or not used? What does it mean to a speaker of a different first language when his or her group members switch to their mother tongue? How does the use of L1 in ESL classes influence the intercultural relations between students who speak different mother tongues? Cooperative learning looks like a promising method for promoting L1 maintenance under certain circumstances, but research needs to be conducted to find out how L1 use in cooperative groups 
might affect relationships between students who come from different ethnic groups and speak different mother tongues.

\section{Cooperative Learning and the Integration of Language and Content Learning}

Another claimed benefit of cooperative learning in the second language classroom is that it makes more readily available to students the content of the curriculum and the language needed to process it. In their detailed account of the principles of cooperative learning for language and content gains, Kagan and McGroarty (1993) argued that:

By providing a variety of ways to expose students to academic content and creating different situations in which they experience and discuss curriculum content, cooperative learning serves both language and content curriculum goals. Through cooperative learning there is improved comprehension and production of language, and both these outcomes aid attainment of subject matter goals. (p. 47)

In her review of the beneficial effects of cooperative learning for second language instruction, McGroarty $(1989,1992)$ examined a number of studies that have been conducted in this area. She summarized her review by stating that the principal curriculum benefit of cooperative learning in the second language classroom is that it offers additional ways to incorporate content areas into language instruction in both ESL and bilingual settings.

Some recent research has looked at cooperation between the expert (i.e., the teacher) and the novices (i.e., the students). In his observational study of a high school foreign language class, Freeman (1992) described how the teacher and her students worked together through cooperative interactions to create a shared understanding of French as both content and activity. The findings show that "the subject matter is not the French language itself, but the interactions which generate it. Interaction produces talk which is channeled or transformed into content" (p. 58).

Mohan and Smith's (1992) research also looked at cooperation between the instructor and the students. The purpose of their study was to investigate how and why a group of Chinese students were able to succeed in a graduate level adult education course although they had inadequate background knowledge about the subject matter and limited English proficiency (as measured by TOEFL tests). Their results reveal that the cooperative interaction of the instructor and the Chinese students constructed a context that enabled the students to develop the background knowledge and gain access to the guidance needed to support work on the assignments. In other words, the instructor as the expert had structured the course interaction and the series of assignments in a way that the novices could participate in the 
interaction and undertake assignments that may otherwise have been beyond their apparent capabilities.

\section{Issues of Prior Knowledge in L1 and the Learning of New Content Knowledge in L2}

Alhough research on cooperation between the teacher and the learner adds a new dimension to our understanding of how cooperation helps students learn language and content simultaneously, more studies are needed to examine how cooperation assists language and content gains among students. In her observational study of a group of monolingual English speaking students working cooperatively on a science project, Webb (1990) noted that students' prior knowledge was of vital importance. Students' discussions that aimed to produce information contained many references to prior knowledge. Webb's research is one of the few studies that discusses the role of students' prior knowledge in their learning of new content knowledge in cooperative groups. Considering ESL students in content classes, what is the role of their prior knowledge in L1 in their learning of new content knowledge in L2? How does cooperative learning help ESL students draw on their prior knowledge in L1 and expand their content knowledge in L2? Answers to these questions will help us better understand the relationship between cooperative learning and the simultaneous learning of language and content in an ESL context.

\section{Cooperative Learning and L2 Learners' Perceptions}

It is noteworthy that much of the discussion of the beneficial effects of cooperative learning has been either from the researcher's or the teacher's point of view. What are the L2 students' perspectives? How do they perceive cooperative tasks? How do they like their experiences when working in groups? Although perceptions from the researcher and the teacher are important, it is L2 students who live the experience of learning a second language in groups. Insights into what they think and believe about cooperative learning can contribute to an understanding of whether, how, and why it benefits them affectively, cognitively, and/or linguistically.

Learning is something students do, not something done to them, be it cooperative learning or second language learning. Students' beliefs and attitudes will influence the implementation and success of cooperative learning in second language classrooms. Of the limited research on ESL learners' perceptions, troubling findings have been reported about students' negative attitudes toward cooperative learning. In a study on ESL students' learning style preferences, Reid (1987) reported that virtually none of her participants chose group learning as a major learning preference. In fact, many ESL 
students indicated that group learning was actually a highly negative format for them.

Reid is not the only person who reports on ESL students' negative attitudes toward cooperative learning. In the description of her students' reaction to this educational practice, Kinsella (1996) noted:

Despite the merits of pairing and grouping strategies, my varied high school and university teaching experiences with the linguistically and culturally diverse student population of San Francisco have made me very aware that not all ESL students embrace collaborative classroom learning with the same zeal as do their instructors. In fact, some immigrant ... students are more likely to react with raised eyebrows and sighs at the prospect of a semester of ongoing participation in peer working groups. In my own classes and those of colleagues, I have observed that well-intended instructional efforts to create more democratic and varied contexts for second language use and growth can be met with reluctance and disorientation on the part of some ESL students. (p. 24)

How do these reports relate to the positive findings on cooperative learning presented in the studies reviewed above? What are the reasons for ESL students' negative responses to cooperative learning? What are the possible sources for their disapproval toward this educational innovation that is supposed to be to their benefit? Research needs to be pursued to understand better how various groups of ESL students perceive cooperative learning and how their sociocultural and educational backgrounds may influence their perceptions.

\section{Issues of Sociocultural Aspects of Cooperative Learning}

\section{in ESL Classrooms}

The sociocultural aspects of cooperative learning in ESL classrooms have not been given serious attention in second language education research. In describing native English-speaking students being introduced to cooperative learning in North American classrooms, Janda (1990) wrote:

When collaboration enters the typical classroom ... it does not enter a vacuum where no social, linguistic or rhetorical activity has taken place previously. Even as we are persuaded that collaboration is an effective practice, we must keep in mind that traditional social and linguistic behaviors are well entrenched in the minds, behaviors, and expectations of students and teachers. (p. 292)

The entrenchment of traditional social behaviors Janda talks about is even more relevant for ESL students coming from a traditional educational background. 
Swain and Miccoli's (1994) research documents a Japanese adult learner's strong feelings of anxiety and depression when working in a small group in a university graduate-level course in Toronto, Canada. Her educational background in Japan not only underprepared her for participation in small group discussion, but also influenced her belief that learning is a goaloriented individual activity and is highly dependent on the teacher. She struggled with tremendous cultural adjustments to adapt to the cooperative course format.

Many ESL students in North American schools come from educational backgrounds where classes are largely teacher-fronted, with the teacher transmitting knowledge and students recording, memorizing, and recalling what is being transmitted. Having seldom experienced other teaching approaches, they tend to take it for granted that this is the only (or at least the best) way to learn. When they are placed in cooperative learning settings, their past experience may come into conflict with their new experience, and their old beliefs with the beliefs strongly held by many North American educators. This sociocultural dimension of learning ESL in small groups needs to be addressed, discussed, and researched. Studies are needed to explore how students' sociocultural backgrounds and past educational experiences contribute to the way they approach and adapt to cooperative learning in ESL classrooms.

\section{Conclusion}

Research in the second language classroom indicates that cooperative learning is potentially beneficial for ESL students in a number of ways. It can maximize second language acquisition by offering opportunities for both language input and output. It can also help students draw on their first language while developing second language skills. It includes opportunities for the integration of language and content learning. Although the reported beneficial effects of cooperative learning in the second language classroom are impressive, more research needs to be done to examine the types of L1 and L2 discourse produced in cooperative groups to find out about student development of academic language. Research also needs to be conducted to investigate first language maintenance in ESL classes where more than one first language is spoken. In particular, it would be important to investigate whether the use of some students' first languages affects the inter-ethnic relationships between these students and students who speak different first languages. In addition, research is needed to look at the role of students' prior knowledge in L1 in their learning of new content knowledge in L2 in cooperative groups. Moreover, research needs to take a sociocultural approach to find out how ESL students perceive cooperative learning and how cultural and educational backgrounds may influence their perceptions. 


\section{The Authors}

Xiaoping Liang is a doctoral candidate in the Department of Language Education, University of British Columbia.

Bernard A. Mohan is a professor in the Department of Language Education, University of British Columbia.

Margaret Early is an associate professor in the Department of Language Education, University of British Columbia.

\section{References}

Auerbach, E.R. (1993). Re-examining English only in the ESL classroom. TESOL Quarterly, 21, 9-32.

Bejarano, Y. (1987). A cooperative small-group methodology in the language classroom. TESOL Quarterly, 27, 483-504.

Coelho, E. (1992). Cooperative learning: Foundation for a communicative curriculum. In C. Kessler (Ed.), Cooperative language learning: A teacher's resource book (pp. 31-49). Englewood Cliffs, NJ: Prentice-Hall.

Coelho, E. (1994). Learning together in the multicultural classroom. Markham, ON: Pippin.

Cohen, E. (1986). Designing group work: Strategies for the heterogeneous classroom. New York: Teachers College Press.

Cohen, E. (1994). Designing group work: Strategies for the heterogeneous classrooms (2nd ed.). Minneapolis, MN: Interaction Book Co.

Collier, V.P. (1987). Age and rate of acquisition of second language for academic purposes. TESOL Quarterly, 21, 617-641.

Collier, V.P. (1995). Promoting academic success for ESL students: Understanding second language acquisition for school. Elizabeth, NJ: New Jersey Teachers of English to Speakers of Other Languages-Bilingual Educators.

Cummins, J. (1984). Language proficiency, bilingualism, and academic achievement. In J. Cummins (Ed.), Bilingualism and special education: Issues in assessment and pedagogy (pp. 130-151). San Diego, CA: College-Hill Press.

Cummins, J. (1992). Language proficiency, bilingualism, and academic achievement. In P.A. Richard-Amato \& M.A. Snow (Eds.), The multicultural classroom: Readings for content area teachers (pp. 16-26). London: Longman.

Deen, J.Y. (1987). An analysis of classroom interaction in a cooperative learning and teacher-centered setting. Unpublished master's thesis, University of California, Los Angeles.

Díaz, S., Moll, L., \& Mehan, H. (1986). Sociocultural resources in instruction: A context-specific approach. In California State Department of Education (Ed.), Beyond language: Social and cultural factors in schooling language minority students (pp. 187-230). Los Angeles, CA: Evaluation, Dissemination and Assessment Center, California State University, Los Angeles.

Doughty, C., \& Pica, T. (1984, March 1984). Information gap tasks: Do they facilitate second language acquisition? Paper presented at the 18th Annual TESOL Conference, Houston.

Dowrick, N. (1993). Talking and learning in pairs: A comparison of two interactive modes for six and seven year old pupils. International Journal of Early Years Education, 1(3), 49-60.

Fathman, A.K., \& Kessler, C. (1993). Cooperative language learning in school contexts. Annual Review of Applied Linguistics, 13, 127-140.

Freeman, D. (1992). Collaboration: Constructing shared understandings in a second language classroom. In D. Nunan (Ed.), Collaborative language learning and teaching (pp. 56-80). Cambridge, UK: Cambridge University Press.

Holt, D.D. (Ed.). (1993). Cooperative learning: A response to linguistic and cultural diversity. McHenry, IL: Center for Applied Linguistics and Delta System. 
Holt, D.D., Chips, B., \& Wallace, D. (1992). Cooperative learning in the secondary school: Maximizing language acquisition, academic achievement, and social development. National Clearinghouse for Bilingual Education.

Jacob, E., Rottenberg, L., Patrick, S., \& Wheeler, E. (1996). Cooperative learning: Context and opportunities for acquiring academic English. TESOL Quarterly, 30, 253-280.

Janda, M.A. (1990). Collaboration in a traditional classroom environment. Written Communication, 7(3), 291-315.

Kagan, S., \& McGroarty, M. (1993). Principles of cooperative learning for language and content gains. In D.D. Holt (Ed.), Cooperative learning: A response to linguistic and cultural diversity (pp. 47-66). McHenry, IL: Center for Applied Linguistics and Delta systems.

Kessler, C. (1992). Cooperative language learning. Englewood Cliffs, NJ: Prentice-Hall Regents.

Kinsella, K. (1996). Designing group work that supports and enhances diverse classroom work styles. TESOL Journal, 6, 24-30.

Long, M.H., Adams, L., McLean, M., \& Castaños, F. (1976). Doing things with words: Verbal interaction in lockstep and small group classroom situations. In R. Crymes \& J. Fanselow (Eds.), On TESOL'76 (pp. 137-153). Washington, DC: TESOL.

Long, M., \& Porter, P.A. (1985). Group work, interlanguage talk and second language acquisition. TESOL Quarterly, 19, 207-228.

McGroarty, M. (1989). The benefits of cooperative learning arrangements in second language instruction. National Association for Bilingual Education Journal, 13(2), 127-143.

McGroarty, M. (1992). Cooperative learning: The benefits for content area teaching. In P.A. Richard \& M.A. Snow (Eds.), The multicultural classroom: Readings for content-area teachers (pp. 58-69). White Plains, NY: Longman.

McGroarty, M. (1993). Cooperative learning and second language acquisition. In D.D. Holt (Ed.), Cooperative learning: A response to linguistic and cultural diversity (pp. 19-46). McHenry, IL: Center for Applied Linguistics and Delta systems.

Mohan, B.A., \& Smith, S.M. (1992). Context and cooperation in academic tasks. In D. Nunan (Ed.), Collaborative language learning and teaching (pp. 81-99). Cambridge, UK: Cambridge University Press.

Neves, A. (1983). The effect of various input on the second language acquisition of Mexican-American children in nine elementary school classrooms. Unpublished doctoral dissertation, Stanford University.

Pica, T. (1987). Second-language acquisition, social interaction, and the classroom. Applied Linguistics, 8, 3-21.

Pica, T., \& Doughty, C. (1985a). Input and interaction in the communicative language classroom: A comparison of teacher-fronted and group activities. In S. Gass \& C. Madden (Eds.), Input in second language acquisition (pp. 115-132). Rowley, MA: Newbury House.

Pica, T., \& Doughty, C. (1985b). The role of group work in classroom second language acquisition. Studies in Second Language Acquisition, 7(2), 233-248.

Reid, J. (1987). The learning style preferences of ESL students. TESOL Quarterly, 21, 87-111.

Sharan, S., Bejarano, Y., Kussell, P., \& Peleg, R. (1984). Achievement in English language and in literature. In S. Sharan, P. Kussell, R. Hertz-Lazarowitz, Y. Bejarano, S. Raviv, \& Y. Sharan (Eds.), Cooperative learning in the classroom: Research in desegregated schools (pp. 46-72). Hillsdale, NJ: Erlbaum.

Swain, M., \& Miccoli, L.S. (1994). Learning in a content-based, collaboratively structured course: The experience of an adult ESL learner. TESL Canada Journal, 12(1), 15-28.

Webb, R. (1990). Working collaboratively on topic tasks. Cambridge Journal of Education, 20, 37-52.

Wong-Fillmore, L., Ammon, P., McLaughlin, B., \& Ammon, M. (1985). Learning English through bilingual instruction: Final report. Washington, DC: National Institute of Education. 